\title{
Age and sustainable labour participation: studying moderating effects
}

\author{
Josine van den Elsen \\ Ministry of Education, Culture and Science, The Haque, The Netherlands, and \\ Brenda Vermeeren \\ Erasmus School of Social and Behavioral Sciences, \\ Erasmus University Rotterdam, Rotterdam, The Netherlands
}

Received 31 October 2018 Revised 10 February 2019 13 July 2019

Accepted 5 October 2019

\begin{abstract}
Purpose - Research findings are ambiguous regarding the effects of age on sustainable labour participation (SLP), defined as the extent to which people are able and willing to conduct their current and future work. The purpose of this paper is to contribute by examining age effects on SLP by focusing on the moderating role of workload.

Design/methodology/approach - A mixed-method study was conducted in 2018. First, a survey was distributed among a sample of 2,149 employees of the Dutch central government. Second, 12 interviews with public sector employees took place to gain greater insight into the quantitative data collected.

Findings - Three components that reflect an employee's SLP were studied: vitality, work ability and employability. The quantitative results, in general, showed that SLP decreased with ageing. However, in contrast to the hypothesis, the results showed a significant positive relationship between age and energy. Moreover, relationships between an employee's age and certain aspects of their SLP were moderated by workload. The interviews helped to interpret these results.

Practical implications - The findings demonstrate that some of the older worker stereotypes are unfounded, and the important practical implications of these are discussed.

Originality/value - Earlier research has produced conflicting findings regarding the relationship between age and (aspects of) SLP. By investigating several aspects of SLP in separate regressions within this research, the specific influences of age have become clearer. Furthermore, the research provides fresh insights into the relationship between age and SLP by including moderating effects of workload.
\end{abstract}

Keywords Age, Employability, Workload, Vitality, Work ability, Sustainable labour participation

Paper type Research paper

\section{Introduction}

In recent decades, demographic changes and public employment policy changes have taken place in nearly all developed countries and, as a result, sustainable labour participation (SLP) has become an urgent theme (Miles, 1999). This study is focusing on SLP in the Netherlands, particularly, the Dutch central government. The Dutch situation regarding demographic and public employment policy changes is similar to other Western European countries (Van Dalen et al., 2010). More specifically, the younger age groups are shrinking, whereas the older age groups are growing (Bradshaw and Mayhew, 2003). In this respect, Busse et al. (2003) estimated, for OECD countries, that the old age dependency ratio will increase from 37 per cent of the working people in 1995-72 per cent in 2050. Therefore, funding pensions is becoming increasingly burdensome and it is seen as necessary that the older employees should continue working (Bloom et al., 2011). As a result, in European

(C) Josine van den Elsen and Brenda Vermeeren. Published by Emerald Publishing Limited. This article is published under the Creative Commons Attribution (CC BY 4.0) licence. Anyone may reproduce, distribute, translate and create derivative works of this article (for both commercial and non-commercial purposes), subject to full attribution to the original publication and authors. The full terms of this licence may be seen at http://creativecommons.org/licences/by/4.0/legalcode

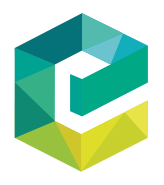

International Journal of Manpower Emerald Publishing Limited DOI 10.1108/IJM-10-2018-036 
countries an increase in employment rates of older workers can be witnessed (Anxo et al., 2012). This is also the case within the Netherlands where the official retirement age has increased from 65 to 67 and three months in combination with an austerity of measures to retire early. This has consequently led to a new group of older workers who did not always choose voluntary to work longer.

In addition, employers and employees are not always positive regarding extending labour participation as there are many negative stereotypes concerning older employees, and older employees sometimes feel little motivation to continue working (Shultz et al., 1998). In this research, we mean with "older workers" people aged above 50 years. This cut-off decision is based on earlier research (cf. Loretto, and White, 2006; Van Dalen et al., 2010) and because governmental programs and HR policies refer to older workers as those older than 50 years (OECD, 2006). A common definition of SLP is based on whether an employee is able to, and wants to, keep working (Semeijn et al., 2015). This concept can be subdivided into the following three dimensions: vitality, work ability and employability (Semeijn et al., 2015). First, vitality refers to the extent to which someone feels lively in terms of energy, resilience and motivation for their work (Strijk et al., 2015). Second, work ability equates to employees who, given their physical and mental state and health, are able to meet the requirements of work (Ilmarinen, 2007). Third, employability is the extent to which employees are able to gain work and remain in work given their competences and the labour market situation (Rothwell and Arnold, 2007).

Overall, the idea prevails in society that SLP in general decreases as people age. Nevertheless, there is considerable uncertainty and contradictions in the literature regarding age effects on SLP (Nauta et al., 2007; Van Vuuren et al., 2011). In response, Ilmarinen (2001) argues that these contradictions may be explained by the differences in work. Therefore, this research poses the following research question:

$R Q$. To what extent does age influence SLP, and what is the role of workload in this relationship within the context of the Dutch central government?

In order to answer this question, the concept of SLP will first be further explored, and hypotheses will be established. Following this, the methods used in this research and the quantitative and qualitative results will be discussed. Finally, conclusions will be drawn, fields for further research will be explored and practical implications will be discussed.

\section{Theoretical background}

\section{Sustainable labour participation}

In earlier research, different conceptualisations of SLP have been introduced. Van der Klink et al. (2011) defined SLP as the extent to which employees are able to function in a healthy way. Van Vuuren et al. (2011) and Semeijn et al. (2015) not only include whether people are able to work but also whether people are willing to carry out their current and future work. In this respect, there are three dimensions that reflect employees' SLP: their vitality, work ability and employability (Semeijn et al., 2015). In this study, we adhere to the latter conceptualisation. To be able to answer the central question, hypotheses have been developed as explained in the following paragraphs.

\section{Age and sustainable labour participation}

First, the literature is contradictory regarding the relationship between age and vitality. Vitality refers to feeling lively in terms of energy, resilience and motivation. Ryan and Frederick (1997) concluded that vitality does not change with age. However, Giles et al. (2000) and Baruch et al. (2014) found that vitality is parabolically related to age. In contrast, Van Vuuren and Marcelissen (2013) conclude that vitality gradually increases over time. In practice, the Netherlands has recently seen a shift to increased labour participation by 
older employees. Due to new regulations, which were implemented in 2014, it is now much more difficult to stop working before the legal retirement age and, further, the retirement age has been increased. As a result, there is now a group of people who could and would have happily ceased work a few years ago who now continue in employment, not because they are still motivated and eager to work, but because they have to what might negatively influence their energy, resilience and motivation. Based on this development, the following hypothesis has been developed:

H1a. The higher the age, the lower the vitality.

Second, we focus on work ability: the degree to which employees are able to meet the requirements of work given their physical and mental state of health. Earlier research has concluded that work ability differs substantially between individuals (Nauta et al., 2004). Nevertheless, most employees believe their work ability decreases with age because their qualifications become less relevant to their work (Ilmarinen, 2001; Van Vuuren and Marcelissen, 2013). Furthermore, health issues occur more often when people are getting older, and good health is vital for work ability (Tengland, 2011). On this basis, the following hypothesis is formulated:

H1b. The higher the age, the lower the work ability.

Third, most employees specialise in a specific area of expertise during their career. As a result, employees tend to lose an overview of their work qualities and possibilities to be widely deployed (Nauta et al., 2005; Tisch, 2015). Therefore, Tisch (2015) states that employability increases in terms of one's own job but decreases for other functions. Indeed, in general, research concludes that employability decreases when people get older (Van der Heijden, 2002; De Lange et al., 2006). In this respect, De Vries et al. (2001) found that the principal target group of employability-stimulating measures is younger people. Furthermore, the likelihood of being long-term unemployed increases as one gets older, which is an indicator of decreasing employability (Euwals et al., 2009). Consequently, the following hypothesis is formulated:

H1c. The higher the age, the lower the employability.

\section{Moderating influence of workload}

As already noted, many contradictions are to be found in previous research with regard to the relationship between age and SLP. Ilmarinen (2001) states that these contradictions might be explained by differences in work characteristics. Moreover, it is still unclear what effect work type has on the relationship between SLP and age (Nauta et al., 2007; Van Vuuren et al., 2011). Employees within the Dutch central government are engaged in a wide range of work types. Since these different work types result in differences in workload these factors are included within this study.

It is possible to classify workload in different ways. Within this research, the division is made between mental, physical and emotional workload (Van Veldhoven and Meijman, 1994). To date, however, little attention has been paid to this distinction in the academic literature. The workload can result in an imbalance between the burdensome requirements of the work and the ability of employees to meet these requirements (Van Veldhoven and Meijman, 1994). A high workload leads to a lower well-being (Ilies et al., 2010) and therefore might have a negative effect on SLP. First, mental workload can be the result of cognitive work and stress (Botterweck, 2003). When people become older, cognitive changes occur for which older people might have problems with a high mental workload (Christensen, 2001). Additionally, quick changes in work can be seen as mental workload and it costs more effort for older employees to adapt these quick changes due to anxiety for changes and learning 
difficulties (Cau-Bareille et al., 2012). As a result, a high mental workload can strengthen the relationship between age and a decreasing SLP. This leads to the following hypothesis:

H2a. Mental workload moderates the relationship between age and SLP in such way that the negative relationship between age and SLP is stronger at high levels of mental workload.

Second, physical workload occurs when someone considers its work as physical heavy as a result of physical strength use, repetitive movements and an uncomfortable working posture (Botterweck, 2003). Older people might have greater trouble in dealing with a high physical workload due to physical changes that occur as part of the aging process (Christensen, 2001):

H2b. Physical workload moderates the relationship between age and SLP in such way that the negative relationship between age and SLP is stronger at high levels of physical workload.

Third, emotional workload occurs when someone is confronted with emotional situations at work (Jettinghoff and Houtman, 2002). Emotional workload mostly occurs within jobs where employees are in contact with clients or citizens. It can be argued that older employees have better coping resources due to more experience than younger employees (Zoer et al., 2011). Nevertheless, when older employees perceive high emotional workload it can strengthen the relationship between age and a decreasing SLP due to their cognitive changes and ability to deal with quick changes in work (Christensen, 2001). This leads to the following hypothesis:

H2c. Emotional workload moderates the relationship between age and SLP in such way that the negative relationship between age and SLP is stronger at high levels of emotional workload.

The established hypotheses regarding the relationship between age and SLP, and the moderation of workload are depicted in the conceptual model (Figure 1).

\section{Method}

Procedure and participants

A mixed-method study was conducted on behalf of the Dutch Ministry of Internal Affairs that included participants from the entire spectrum of the Dutch central government. The government is the biggest employer in the Netherlands. The Dutch central government is characterised by a relatively old working population (age $=47.5$ in 2017) in comparison to the rest of the labour force within the Netherlands (age $=42$ in 2017). According to OECD research, the total workforce will age and because this development already took place within the Dutch national government, it can give insights for other organisations in the future. The central

Figure 1.

Conceptual model

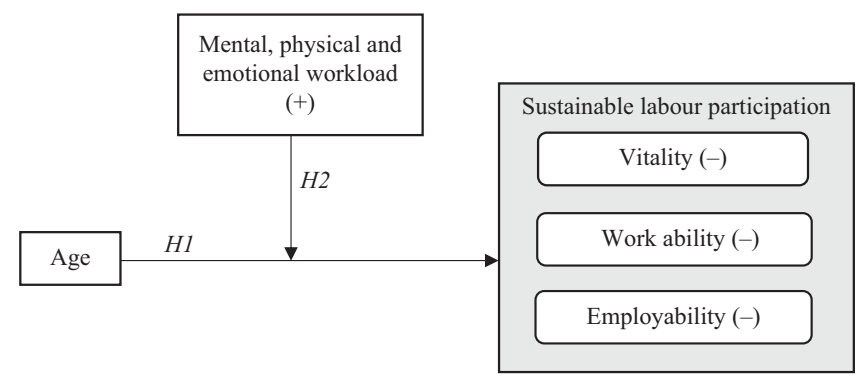


government concerns a broad spectrum of different types of jobs which is relevant for this research, such as on the one hand executive jobs as prison guards and employees at the State Water Authority and on the other hand people with more policy work at the tax authorities or at a Ministry. Due to this broad spectrum of job types it is possible to include the three types of workload within this research. In total, $N=120,000$ employees work for the Dutch national government. To guarantee that our sample included sufficient older employees, three strata were defined (aged $<50,50-60,>60$ ). Further, to ensure an adequate quantity of employees with more physical jobs, this group was over-represented in the sample. A random sampling strategy was used on a database of all Dutch central government employees. Questionnaires were distributed via e-mail to a total of 6,300 employees, on 10 April 2018. Eventually, 2,149 employees completed the whole questionnaire (response rate of 34 per cent). Overall, within the three age cohorts, there were more men than women, making the sample representative of the workforce. It is not practical to judge the representativeness of our sample regarding salary and educational level because of the oversampling of some groups within our study. To help in interpreting the results of the quantitative research, 12 employees were also interviewed. These interviewees were selected from those participants who indicated that they were willing to take part in an interview.

\section{Measurements}

The first question concerned chronological age in years. This was measured on a continuous scale using a drop-down menu of birth year ranging from 1945 to 2000.

Second, vitality was measured by using the Vita-16 questionnaire (Strijk et al., 2015). This questionnaire consists of 16 items and measures vitality in terms of the following three domains: energy (five items), motivation (six items) and resilience (five items). An example item in the "energy" category being "I have enough energy to do all my daily activities". Under the "motivation" category, an example item is "If I have a goal, I immediately plan to achieve this goal". Finally, an example question in the last "resilience" category is "I can deal well with setbacks". The respondents answered each item on a seven-point Likert scale ( $1=$ seldom, $7=$ always). The Cronbach's $\alpha$ for the energy scale was $\alpha=0.89$, for motivation $\alpha=0.90$ and for resilience $\alpha=0.88$, all indicating an acceptable measure.

Third, work ability was measured using a single question from the Work Ability Index (Ilmarinen, 2007). Before answering this question, the participants were provided with a definition of work ability. Participants were then asked to assess their work ability answering the following question: "If you give your work ability in the best period of your life 10 points, how many points would you give your work ability at the moment?" This question was answered using a drop-down menu (1-10).

Fourth, employability was measured by a shortened version of the questionnaire by Rothwell and Arnold (2007) consisting of six questions. This questionnaire distinguishes between internal employability (getting opportunities and job security in the current job) and external employability (perceived chances of finding a job elsewhere), with three questions on each. An example question on internal employability is: "Even if there was downsizing in this organisation, I am confident that I would be retained". A sample question on external employability is: "I could easily retrain to make myself more employable elsewhere". Participants were asked to answer these questions on a five-point Likert scale ( $1=$ completely disagree, $5=$ completely agree). The scale reliabilities were, for internal employability, $\alpha=0.67$, and, for external employability, $\alpha=0.75$. As such, the Cronbach's $\alpha$ for internal employability was slightly below the usual acceptability threshold (0.7). Nevertheless, to be able to compare the findings of this study with earlier research, all the scale items were retained in the analysis.

Fifth, workload was measured using items from the "Working conditions" national survey (Koppers et al., 2012). This survey measured workload in terms of three domains: 
emotional (four items), mental (three items) and physical (three items) workload. An example item on emotional workload is: "Does your work place you in difficult emotional situations?" A sample question from the mental workload scale is "Does your work require intensive thinking?" and, from the physical workload scale: "Do you work in a physically uncomfortable position?" These questions were measured on a four-point Likert scale $(1=$ never, $4=$ often). The Cronbach's $\alpha$ of the emotional workload scale was acceptable at $\alpha=0.73$. However, on analysis, the factor structure of the scale measuring mental workload was not supported. Therefore, one item was excluded from the analyses. The Pearson $r$ between the remaining two items of the mental workload scale was acceptable $(r=0.711)$. Furthermore, the proposed physical workload scale had a very low Cronbach's $\alpha(\alpha=0.32)$. Therefore, these three items were not formed into a scale but treated as three independent items in the subsequent analysis.

Finally, several personal-level control variables were included that had been previously found to affect SLP. First, we included gender $(0=$ man, $1=$ woman $)$. Reflecting the Dutch education system, educational level was subdivided into six categories $(1=$ primary education; $2=$ secondary vocational education; $3=$ preparatory academic education; $4=$ vocational education; $5=$ higher vocational education; and $6=$ academic education). This variable was, as is generally the approach, treated as a continuous variable (see Van Jaarsveld et al., 2010). Additionally, salary was measured in terms of an employee's salary scale (Dutch national government employees are employed on one of 19 scales with associated minimum and maximum salaries but some overlap). Finally, the years of experience in the current job ("tenure") were included and measured using three categories ( $<5,5-15,>15$ years).

The subsequent interviews were semi-structured to aid comparability. An interview guideline was used, and the interview was based on 12 questions. Prior to the interviews, the respondents were informed about what the study entails and what their role is within the study. With the permission of the participants, the interviews were recorded and later transcribed. This approach allowed data to be collected in a structured way while allowing flexibility to go into greater depth when necessary.

\section{Analyses}

The data analysis employed SPSS Statistics. First, model assumptions such as normality, linear comparison and homoscedasticity were checked and confirmed. For the relationships between age and motivation and age and external employability there are indications in the data that these relationships are curvilinear. Second, the hypothesised relationships were explored through bivariate correlation analyses. Third, the hypotheses were tested using linear regression analysis with an ordinary least square run. Within the regression analysis, checks have been executed on the curvilinear relationships.

After the interviews took place, they were all transcribed in the same way. Furthermore, member checking was conducted in which the participants received their own transcripts for reviewing and their comments were processed. All the participants confirmed that the transcription reflected their statements in the right way. Finally, the interview transcripts were thematically analysed using Atlas.ti.

\section{Quantitative results}

Table I shows the means, standard deviations and correlations of the collected data. When interpreting the means and standard deviations of the various variables, it is important to note the different scales which were used to measure these variables. Therefore, the scales used are placed between parentheses. Furthermore, Table I shows that most variables are significantly correlated with at least some of the other variables $(p<0.01)$. The first observation is that age has significant negative relationships with motivation, employability and work ability. However, age is not significantly correlated with two aspects of vitality: 


\begin{tabular}{|c|c|c|c|c|c|c|c|c|c|}
\hline Variable & 1 & 2 & 3 & 4 & 5 & 6 & 7 & 8 & \\
\hline $\begin{array}{l}\text { 1. Age } \\
\text { 2. Energy (/7) }\end{array}$ & - & & & & & & & & \\
\hline & 0.018 & - & - & & & & & & \\
\hline $\begin{array}{l}\text { 3. Motivation }(/ 7) \\
\text { 4. Resilience }(/ 7)\end{array}$ & $\begin{array}{c}-0.121^{* * *} \\
0.009\end{array}$ & $\begin{array}{l}0.562 * * \\
0.602 * *\end{array}$ & $\stackrel{-}{0.580 * *}$ & & & & & & \\
\hline 5. Internal & & & & & & & & & \\
\hline $\begin{array}{l}\text { Employability (/5) } \\
\text { 6. External }\end{array}$ & $-0.081 * *$ & $0.356^{* *}$ & $0.353 * *$ & $0.335^{* *}$ & - & & & & \\
\hline Employability (/5) & -0.350 ** & $0.278 * *$ & $0.327 * *$ & $0.305 * *$ & $0.425 * *$ & - & & & \\
\hline 7. Work ability (/10) & $-0.057 * *$ & $0.537 * *$ & $0.328 * *$ & $0.356^{* * *}$ & $0.284^{* * *}$ & $0.206 * *$ & - & & \\
\hline 8. Mental WL (/4) & -0.011 & 0.020 & $0.083 * *$ & $0.108 * *$ & -0.014 & -0.015 & $0.048^{*}$ & - & \\
\hline 9. Emotional WL (/4) & $-0.064 * *$ & $-0.144 * *$ & -0.027 & $-0.066^{* *}$ & $-0.056^{* *}$ & 0.007 & $-0.096 * *$ & $0.214^{* *}$ & \\
\hline 10. Physical WL1 (/4) & -0.018 & 0.034 & -0.009 & 0.010 & -0.030 & 0.036 & $-0.053^{*}$ & $0.046^{* *}$ & \\
\hline 11. Physical WL2 (/4) & -0.032 & $-0.127 * *$ & $-0.051^{*}$ & $-0.056 * *$ & $-0.102^{* *}$ & -0.020 & $-0.116 * *$ & $0.063 * *$ & \\
\hline 12. Physical WL3 (/4) & $0.044 *$ & $-0.083^{* *}$ & -0.036 & $-0.093 * *$ & $-0.135^{* *}$ & $-0.116^{* *}$ & $-0.066^{* *}$ & $0.059 * *$ & \\
\hline 13. Gender & $-0.199 * *$ & $-0.050^{*}$ & $0.086^{* *}$ & $-0.055^{* *}$ & -0.018 & $0.089 * *$ & 0.019 & -0.004 & \\
\hline 14. Education & $-0.253^{* *}$ & 0.030 & $0.103^{* *}$ & $0.052^{*}$ & $0.175^{* *}$ & $0.223 * *$ & $0.126^{* *}$ & $0.078 * *$ & \\
\hline 15. Tenure & $0.626^{* *}$ & $-0.048 *$ & $-0.117 * *$ & -0.020 & $-0.095 * *$ & $-0.325 * *$ & $-0.071^{* *}$ & $-0.053^{*}$ & \\
\hline 16. Salary & $0.097 * *$ & 0.040 & $0.066^{* *}$ & $0.064^{* *}$ & $0.232^{* *}$ & $0.056^{* *}$ & $0.166^{* *}$ & 0.023 & \\
\hline M & 52.3 & 4.5 & 4.9 & 5.0 & 3.3 & 3.0 & 8.0 & 3.4 & \\
\hline SD & 10.5 & 1.2 & 1.1 & 1.0 & 0.8 & 0.9 & 1.5 & 3.4 & \\
\hline Variable & 9 & 10 & 11 & 12 & 13 & 14 & 15 & 16 & \\
\hline 1. Age & & & & & & & & & \\
\hline 2. Energy (/7) & & & & & & & & & \\
\hline 3. Motivation $(/ 7)$ & & & & & & & & & \\
\hline 4. Resilience (/7) & & & & & & & & & \\
\hline 5. Internal & & & & & & & & & \\
\hline Employability (/5) & & & & & & & & & \\
\hline 6. External & & & & & & & & & \\
\hline Employability (/5) & & & & & & & & & \\
\hline 7. Work ability (/10) & & & & & & & & & \\
\hline 8. Mental WL (/4) & & & & & & & & & \\
\hline 9. Emotional WL (/4) & - & & & & & & & & \\
\hline 10. Physical WL1 (/4) & $0.205^{* * *}$ & - & & & & & & & \\
\hline 11. Physical WL2 (/4) & $0.226 * *$ & $0.308 * *$ & - & & & & & & \\
\hline 12. Physical WL3 (/4) & -0.009 & 0.006 & $0.176 * *$ & - & & & & & \\
\hline 13. Gender & $-0.117^{* *}$ & $-0.104 * *$ & -0.041 & $0.098 * *$ & - & & & & \\
\hline 14. Education & $0.067 * *$ & -0.186 ** & $-0.059 * *$ & $-0.089 * *$ & 0.018 & - & & & \\
\hline 15. Tenure & 0.013 & 0.034 & 0.022 & $0.073 * *$ & $-0.132^{* *}$ & $-0.235^{* *}$ & - & & \\
\hline 16. Salary & 0.033 & $-0.301 * *$ & $-0.112^{* *}$ & $-0.121^{* *}$ & $-0.181^{* *}$ & $0.577 * *$ & $0.051^{*}$ & - & \\
\hline M & 1.8 & 1.2 & 1.6 & 2.5 & 0.45 & 4.4 & 2.6 & 9.0 & \\
\hline SD & 0.5 & 0.5 & 0.7 & 0.9 & 0.5 & 1.3 & 0.7 & 2.6 & \\
\hline \multicolumn{9}{|c|}{$\begin{array}{l}\text { Notes: WL1, first item of workload; WL2, second item of workload; WL3, third item of workload. }{ }^{*} p<0.05 \text {; } \\
* * p<0.01\end{array}$} & $\begin{array}{r}\text { Table I. } \\
\text { Correlations }\end{array}$ \\
\hline
\end{tabular}

energy and resilience. Further, mental workload does not significantly correlate with energy or with internal and external employability, while emotional workload does not show a significant correlation with either motivation or external employability. Additionally, the first component of physical workload (WL1) is not significantly correlated with energy, motivation, resilience, internal and external employability and work ability.

To test the first hypothesis, we conducted a linear regression analysis and the results shown in Table II test the three components of $H 1$. The higher the age, the lower the SLP (vitality, work ability and employability). The various sub-dimensions of SLP are tested in six different regression analyses, using two steps with the linear term of age, followed by a third step which includes the quadratic term of age (labelled as age squared in Table II). 
IJM

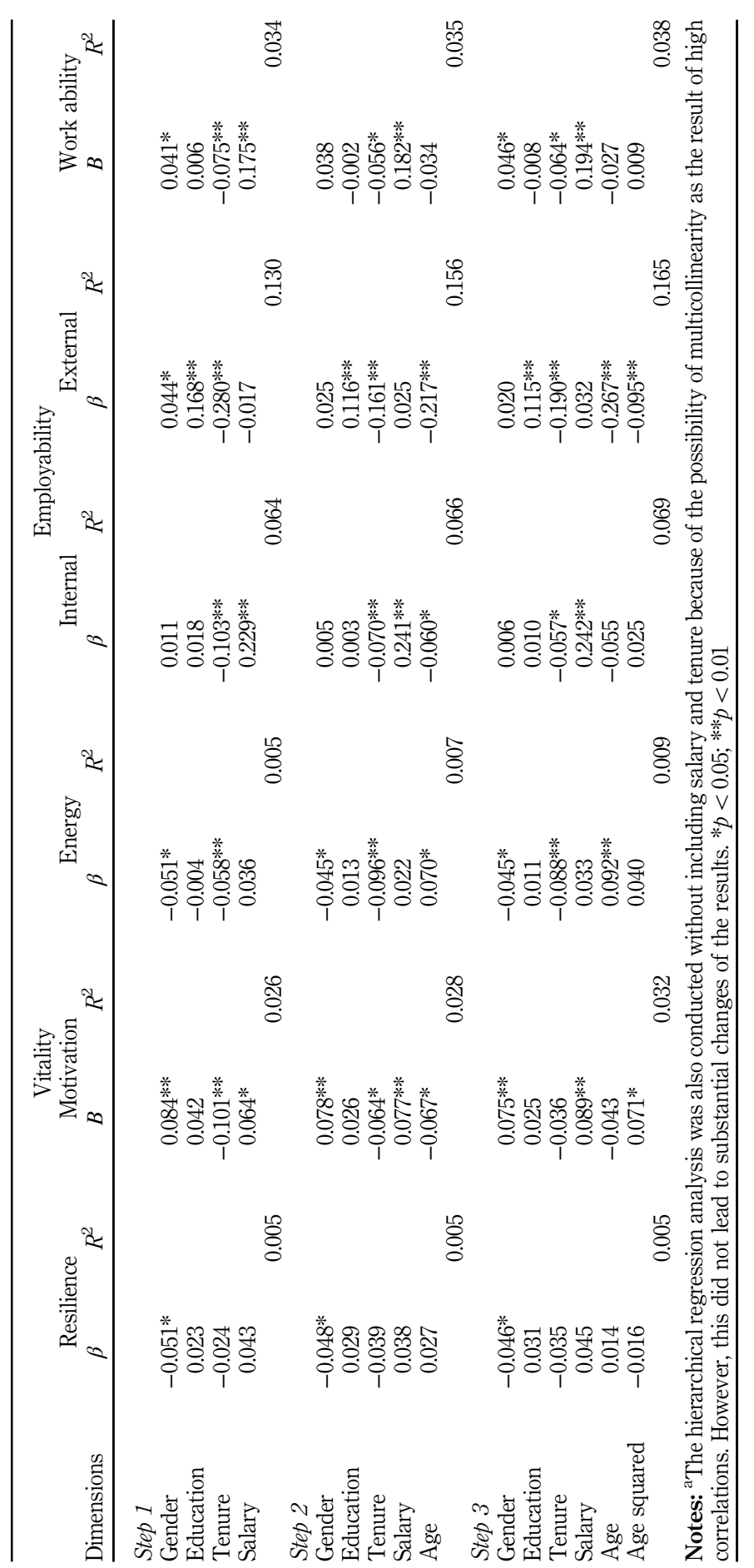

Table II.

Hierarchical regression analysis of age on sustainable labour participation 
Our first observation is that the central independent variable, age, shows a significant U- shaped curvilinear relationship with motivation $\left(\beta=0.071^{*}\right)$. This indicates that people with a moderate age have the lowest level of motivation, whereas younger or older employees have a higher motivation. Moreover, age and energy show, in contrast to our initial assumption, a significant positive relationship $\left(\beta=0.070^{*}\right)$. We interpret this as meaning that, as people age, they feel they have more energy. Further, there is no significant relationship between age and resilience. Therefore, $H 1 a$ is only partially supported. Since there was no significant relationship between age and work ability, $H 1 b$ has to be rejected. Third, the results indicate a significant negative relationship between age and internal employability $\left(\beta=-0.060^{*}\right)$. In addition, age shows a linear significant relationship with external employability $\left(\beta=-0.267^{* *}\right)$ and a fairly flat inverted U-shaped curvilinear relationship with external employability $\left(\beta=-0.095^{* *}\right)$. These results indicate that, when employees become older, they feel their internal and external employability have reduced, but that the relationship between age and external employability is also slightly inverted U-shaped in which the group between 50- and 60-year-old showed a small upwards deviation from the negative linear relationship and therefore $H 1 c$ is partially supported.

Table III shows the results of the regression analyses including the effect of age plus the three different kinds of workload as interaction effects. This analysis was executed to test the second hypothesis: mental, physical and emotional workload moderate the relationship between age and SLP in such way that the negative relationship between age and SLP is stronger at high levels of mental, physical and emotional workload. This analysis was also executed using two steps with the linear term of age followed by a third step with the quadratic term of age for motivation and external employability.

This analysis found six interaction effects, with only the linear term of age. However, the interaction effect on motivation disappears while including the quadratic term of age. First, we consider the results concerning the influence of physical workload on two of the three dimensions of vitality. Given the low Cronbach's $\alpha$ of the physical workload scale, the three items that form this scale were tested separately in the regression analysis. The subsequent results show that the first item of physical workload (degree of strength use) moderates two of the three dimensions of vitality (resilience $\beta=-0.063 * *$; energy $\beta=-0.076 * *$ ). To explain the moderating effects in all the figures, low age means 41.8 years old (mean $-1 \mathrm{SD}$ ) and high age means 62.8 years old (mean $+1 \mathrm{SD}$ ).

The result in Figure 2a implies that physical workload, i.e. the need to employ physical strength in work, moderates the relationship between age and resilience in such way that at a high age a high degree of physical strength has a negative effect on the resilience. This outcome is in line with $H 2$.

The result shown in Figure $2 \mathrm{~b}$ shows that physical workload moderates the relationship between age and energy in such way that at a high age a high degree of physical strength has a negative effect on the energy. This is in line with $H 2$.

The second item of physical workload (uncomfortable working posture) was found to moderate the relationship between age and work ability $\left(\beta=0.064^{* *}\right)$. This moderation effect is shown in Figure 3 and shows that that at a high age a low degree of physical workload has a negative effect on work ability whereas a high workload does not seem to have much effect. This is not in line with $\mathrm{H} 2$ as we assumed that the negative relationship between age and work ability is stronger at high levels of physical workload than at low levels of physical workload.

Furthermore, the third item of physical workload (repetitive movements) moderates the relationship between age and resilience $\left(\beta=-0.064^{* *}\right)$. The results in Figure 4 show that physical workload (repetitive movements) moderates the relationship between age and resilience in such way that at a high age a high degree of physical workload has a negative effect on the resilience. This outcome is in line with $H 2$. 

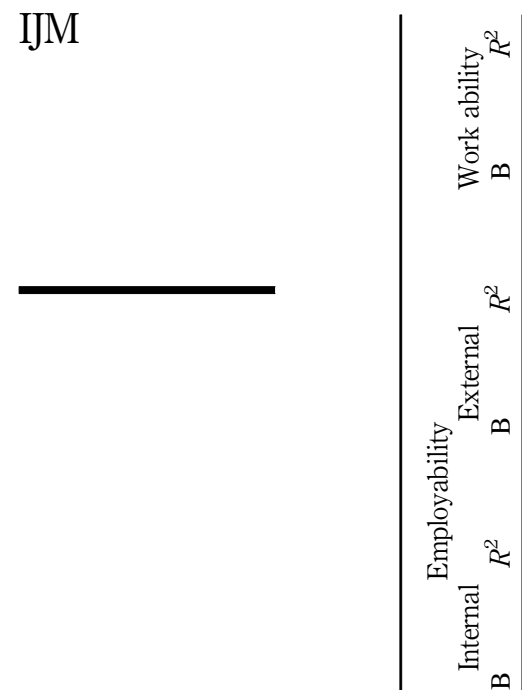

ஜి

ญै

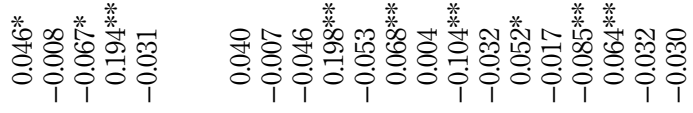

$\stackrel{-10}{0}$

ำ

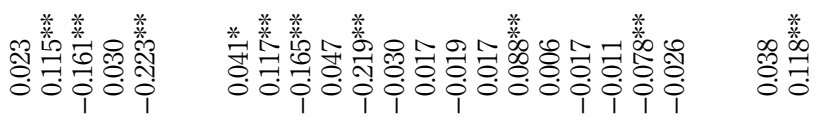

ஜ્

$\stackrel{8}{\infty}$

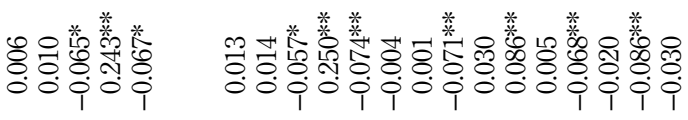

\begin{tabular}{ll}
8 & 8 \\
\hline & 8
\end{tabular}

悹

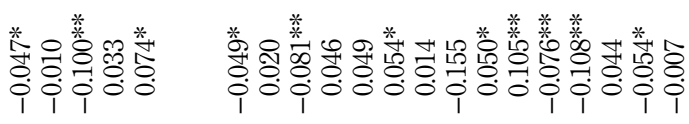

$\stackrel{\mathscr{B}}{0}$

$\stackrel{9}{\circ}$

点葛

Table III.

Hierarchical

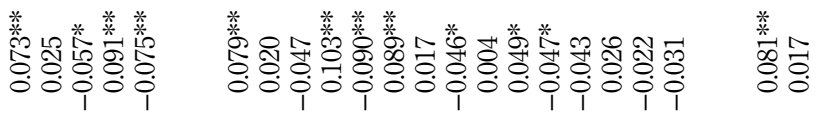

8

쿵

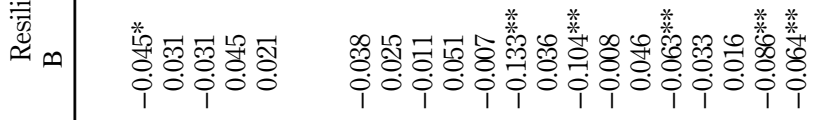

论

.




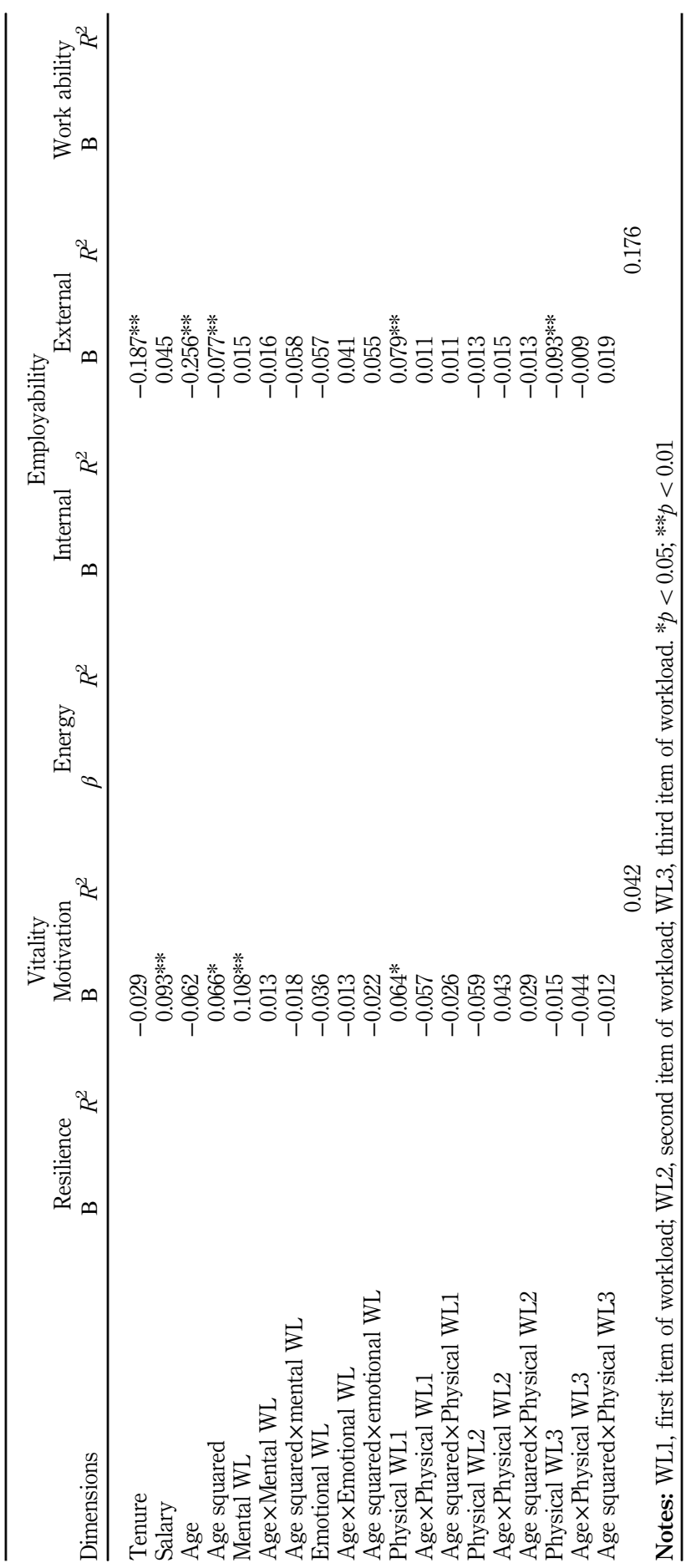

Age and SLP 
IJM

Figure 2.

(a) Moderation effect of physical workload 1 on age and resilience; (b) moderation effect of physical workload 1 on age and energy

Figure 3.

Moderation effect of physical workload 2 on age and work ability (a)

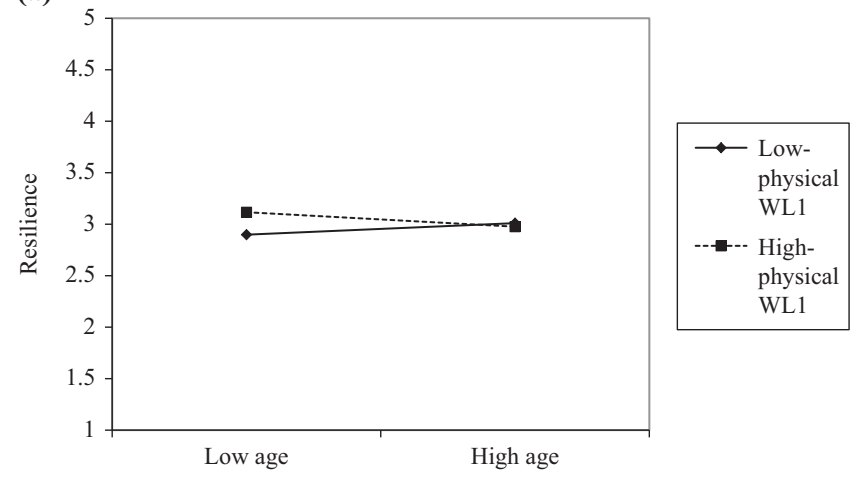

(b)
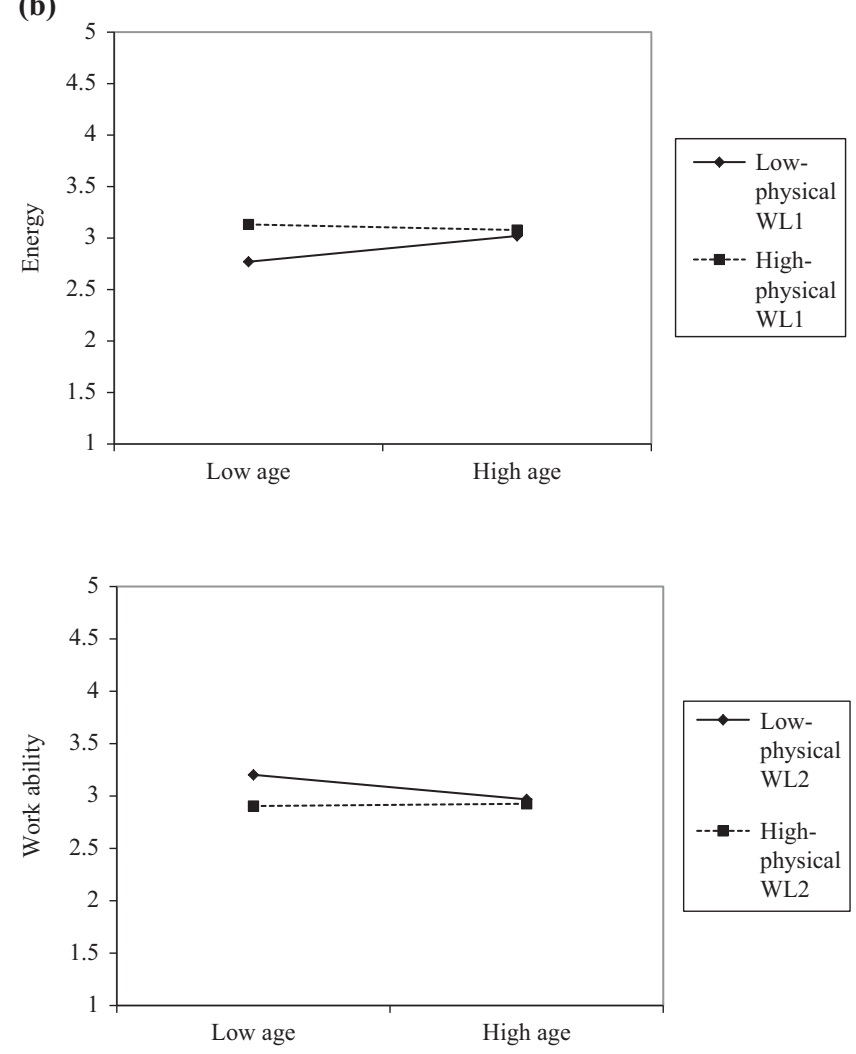

Finally, emotional workload moderates the relationship between age and energy $\left(\beta=-0.50^{*}\right)$. This moderation effect is shown in Figure 5 and it shows that at a high age a high degree of emotional workload has a positive effect on the energy. This is not in line with Hypothesis 2 although it shows that a low emotional workload has a more positive effect on energy than a high emotional workload.

Overall, the second hypothesis is partially supported. 


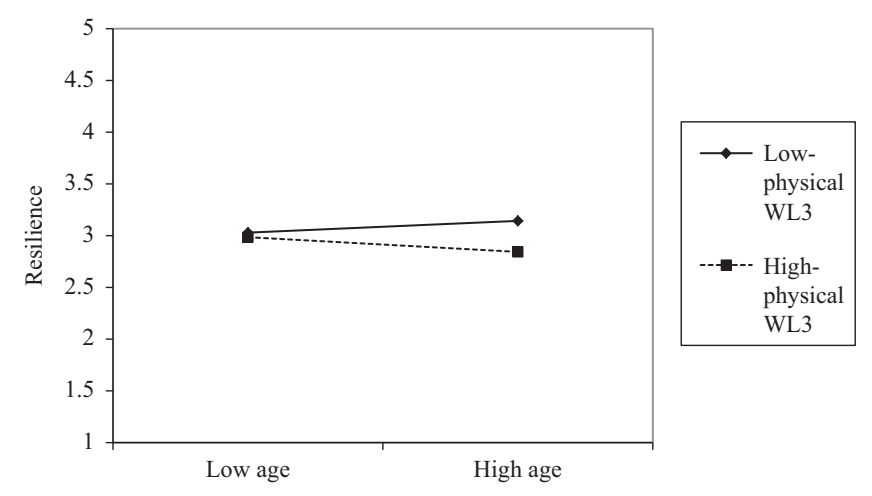

Age and SLP

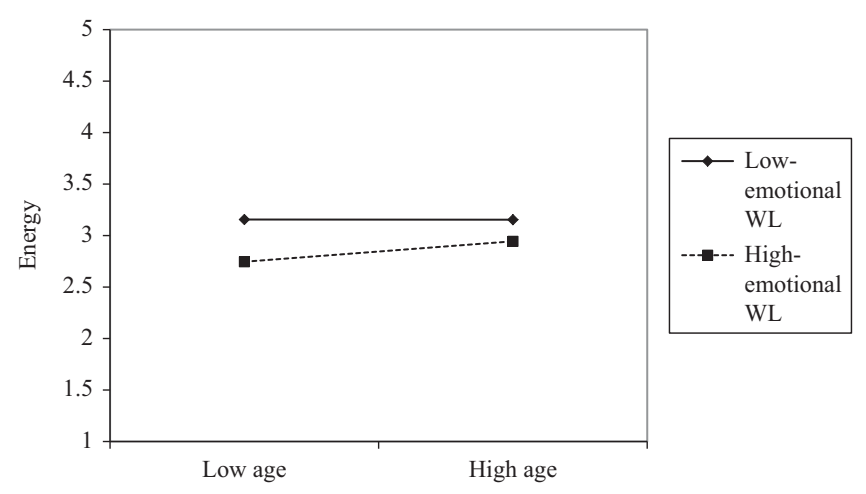

Figure 4.

Moderation effect of physical workload 3 on age and resilience

Figure 5. Moderation effect of emotional workload on age and energy

\section{Qualitative results}

Further to the quantitative analyses, 12 employees were interviewed. The intention was not to further test the hypotheses, but to get a greater sense of the quantitative output.

\section{Age and vitality}

The interviewees experienced that age has no relationship with resilience and mentioned that resilience was more likely to be connected to tenure rather than age. Participants thought it easier to rebound when a similar situation had occurred in the past. One interviewee expressed it as follows: "I think situations were harder when I was 18 than now, because I have seen more situations". However, despite these sentiments, the quantitative results show no relationship between tenure and resilience.

Furthermore, the interviewees experienced that motivation decreases with age, which is similar to the quantitative result. For example, some interviewees mentioned that their work had changed so much that they enjoy it less than before and that they did not experience opportunities to change jobs. As a consequence, their motivation decreases, and one employee expressed it as follows: "In order to facilitate the customer in a better way, it takes longer than before due to work changes. This leads to many complaints, which sometimes makes me less motivated".

Surprisingly given the hypothesis, interviewees were saying that they had more energy by getting older. This is in line with the quantitative result. However, the respondents 
indicated that one's actual energy does not increase but, by getting older, it becomes easier to deal more consciously with energy levels. As a respondent put it: "I think you distribute your energy in a smarter way when you get older".

\section{Age and work ability}

The interviewees confirmed the widely accepted assumption that health issues increase with age. Nevertheless, they believed that these issues did not affect their work, so that their work ability does not decrease. The response of the interviewees is thereby in line with the quantitative result which does not show a relationship between age and work ability. An interviewee expressed this as follows: "Yes, of course you have to deal with some health issues, but you need to handle this. In my case, with some pills, and I can continue doing my work well".

\section{Age and employability}

The respondents clearly experienced that the higher the age, the lower the employability becomes, which corresponds to the quantitative results. Employees mentioned that their job opportunities had decreased as they got older, because they felt that most opportunities were given to younger people. Respondents also commented that, due to age discrimination, they experience less internal and external job opportunities. An interviewee observed: "Put some job candidates in a row, they always prefer to drop the oldest one first".

\section{Workload as moderator}

The respondents explained that mental workload does not influence the relationship between age and SLP. Particularly, by explaining that mental workload is part of the job and therefore they do not see it as a burden. This is in line with the quantitative result. It was difficult for the interviewees to reflect on emotional workload influencing the relationship between age and SLP. They thought that it becomes easier to cope with difficult situations as one becomes older. However, expect for energy, no moderating effect of emotional workload was proved by the quantitative results. Additionally, the respondents mentioned that their work was not very physical even when their work was not deskbound. However, they believed that this physical inactivity in their work is a factor that leads to physical complaints, such as backache.

\section{Discussion and conclusions}

Fuelled by the demographic shift, SLP is high on the agenda of HR managers (Froehlich et al., 2014). SLP is in this research distinguished in vitality, employability and work ability. The research reported here provides fresh insights into the relationship between age and SLP by including moderating effects of workload in the analysis. Overall, this research answers the following research question:

$R Q 1$. To what extent does age influence SLP, and what is the role of workload in this relationship within the context of the Dutch central government?

Earlier research has produced conflicting findings regarding the relationship between age and the first part of SLP: vitality (Ryan and Frederick, 1997; Baruch et al., 2014; Van Vuuren and Marcelissen, 2013). By investigating the three aspects of vitality (motivation, energy and resilience) in separate regressions within this research, the specific influences of age on these three aspects of vitality have become clearer. That is, it appears that overall employees between 50- and 60-year-old show less motivation than employees at a lower and higher age, older employees have more energy, but the resilience of older employees does not significantly differ from younger employees. Regarding for example energy, the interviewees mention some insightful experiences. They mentioned that older employees experience more energy because 
they are more conscious about their energy and know how to divide it in a better way. The differences found between the aspects of vitality might explain the conflicting findings in previous research and is therefore an important contribution to the literature.

The further finding that in general employability is lower for older employees is in line with earlier research (Van der Heijden, 2002; De Lange et al., 2006). However, the results also indicate a fairly flat inverted U-shaped relationship between age and external employability. Our interviews attributed the lower employability for older employees to a feeling of age discrimination. The finding that the older individuals feel discriminated against because of their age has been supported in much research (Ayalon, 2014; Jackson, 2013; Noonan, 2005). In this respect, previous research for example showed that approximately half of employers associate the ageing of the personnel with a growing gap between labour costs and productivity. The expected labour cost productivity gap negatively affects both recruitment and retention of older workers (Conen et al., 2012). Therefore, we would recommend investigating to what extent age discrimination is real and perceived within the Dutch central government. Additionally, if age discrimination does takes place, it is important to investigate any consequential problems. Research has shown that age discrimination leads to applications being rejected and less access to training and education facilities (Levy and Macdonald, 2016). Age discrimination is largely a consequence of negative stereotyping, seeing the older employees as having less energy and being less healthy (Jackson, 2013). In contrast, this research provides empirical evidence that challenges these stereotypes.

Within scientific research, there are conflicting findings regarding the effect of age on work ability. In our research, we failed to find any relationship between age and work ability. This is consistent with Nauta et al. (2004) who showed that work ability is not age-related but personal. While Van Vuuren and Marcelissen (2013) showed that work ability decreases with age, they noted that very few older people sense low work ability. Similarly, within our interviews, the respondents claimed that they did not experience their work ability decreasing as they got older.

Previous research has provided arguments for why differences in work give contradictory findings regarding the relationship between age and SLP (Ilmarinen, 2001). By including mental, physical and emotional workload within this research, it has become possible to nuance these aspects on which very little scientific research is available. An important finding is that physical workload influences the relationship between age and both vitality and work ability. First, at a high age a high degree of physical strength has a negative relationship with resilience and energy of employees. This is in line with the expectations. Second, in contrast to the expectations we found that at a high age a low degree of physical workload (uncomfortable physical working posture) has a negative relationship with work ability whereas a high workload does not show a relationship. Furthermore, we found that at a high age a high degree of emotional workload has a positive relationship with energy, although it shows that a low emotional workload has a more positive relationship with energy than a high emotional workload. In our quantitative and qualitative data, we could not find a good explanation, but it might be explained by a bias which occurred when respondents filled in the questionnaire. Older employees within physical or emotional jobs might be very conscious about their work ability and energy and because older employees do not want to be inferior to others, they might score themselves higher on these aspects. These moderating results emphasise the importance of giving attention to workload when studying age effects. The results in this research lead to some recommendations for areas where future research could usefully contribute, which will be discussed below.

\section{Limitations and future research}

Despite the contributions made, this study has some limitations that provide areas for future research. First, the questionnaire for the quantitative data collection measured perceptions: 
that is, the participants scored themselves on the various aspects. As such, the conclusions are based on subjective data, while perceptions can change over time and, consequently, repeatability is not assured. Despite this downside, it is not clear how one could objectively measure SLP since it is very personal for employees and, as such, measuring perceptions within this research can be seen as adding value.

A second limitation is the fact that tenure was only measured in terms of one of three categories in this research $(<5,5-15,>15$ years). The subsequent analysis shows that tenure has more negative effects than age itself. To be more specific, tenure leads to a decrease in all the factors contributing to SLP (apart from resilience). Given the relatively course nature of our tenure measurement instrument, it is unfortunately not possible to fully reveal its influence. Greater insight into the relationship between tenure and SLP could be achieved by adopting a continuous scale. Such research could shed light on when it is perhaps best to remain in the same function and when it is time to seek a fresh position. Furthermore, this research shows some significant relationships between gender and SLP. However, gender is not within the scope of this article but can be relevant for future research as earlier research shows differences in employment and retirement age between men and women (Van Dalen et al., 2010).

Besides, a third limitation is the relatively low response rate (34 per cent). At the same time, this response rate is not unusual in this kind of studies (Baruch and Holtom, 2008). Although it may lead to a form of sample bias, there is no guarantee that a high response rate results in no sample bias (Visser et al., 1996). We did not have access to data that would permit the evaluation of a possible response bias, but we are not aware of any reasons that could contribute to a lack of desire to participate among specific groups.

A fourth limitation is that, although this research included some insightful qualitative data from interviews, the interviewees were selected from those participants who indicated that they were willing to participate in the interview. It is necessary to gather more qualitative data in order to interpret the relationship between age and SLP in a more detailed way.

In addition, a fifth limitation is that it is not possible to firmly establish cause-consequence relationships. Since this research is cross-sectional, it is not possible to confidently say that, for example, employability decreases over time. To justify such statements, it is necessary to follow people over time. In this study, it is only possible to identify differences between the younger and older cohorts and the actual causal relationship remains unexposed. Therefore, we would encourage researchers to follow employees over a lengthy period. With the information resulting from such a longitudinal study, it becomes possible to draw reliable causal conclusions. However, such extended research requires considerable commitment.

Finally, a sixth limitation is about the generalisability of the findings. The Dutch central government under study forms on the one hand a particular population as described in the method section. On the other hand, OECD research shows that the Netherlands is a very similar country in comparison to other European countries in the area of policy and demographic changes. In this respect, it is hard to say to what extend the results of this research are generalisable to other organisations and countries. More research is needed to validate the results within this research to other settings. At the same time, this research provides some valuable insights for organisations facing an increase in the official retirement age and who have to cope with older employees and SLP. These insights will be explained in the next paragraph.

\section{Practical implications}

The first practical implication relates to the finding that older employees feel that their employability is lower than for younger employees. That is, they have the feeling that they have fewer opportunities within their work than their younger colleagues and feel they will not be able to find a job elsewhere. The interviews provided the insight that the older employees feel left out or even excluded. Therefore, it is important to give them the same opportunities. 
In addition, improved communication is needed for both employers and employees since the widely held stereotypes do not always hold.

Another implication is based on the finding that motivation is the highest at a young and older age, but lower for moderate aged employees. This finding was explained in the interviews by the fact that work is changing a lot and, in some circumstances, it therefore becomes less attractive. This particularly seems to account for moderate aged employees but when the retirement age comes into picture, they might feel more motivated again. Further, older people feel there are fewer opportunities to change their work when they no longer enjoy their current role, and that they are relatively unlikely to be offered promotion. Therefore, alongside providing new job opportunities for moderate aged employees, it is important to keep everyone involved in their current function. Job crafting might be a useful instrument here since research shows that this is a good way to improve workers' motivation (Tims and Bakker, 2010).

The third implication is based on the finding that physical workload strengthens the relationship between age and various sub-components of decreasing SLP. That is, we found that such workloads can cause problems and have a negative effect on older employees' SLP. Therefore, it would be worthwhile to investigate which aspects of the work create this physical overload. Next, one needs to consider how to change these aspects of work, for example by offering other approaches that rely less on physical strength.

\section{References}

Anxo, D., Ericson, T. and Jolivet, A. (2012), "Working longer in European countries: underestimated and unexpected effects", International Journal of Manpower, Vol. 33 No. 6, pp. 612-628.

Ayalon, L. (2014), "Perceived age, gender, and racial/ethnic discrimination in Europe: results from the European social survey", Educational Gerontology, Vol. 7 No. 40, pp. 499-517.

Baruch, Y. and Holtom, B.C. (2008), "Survey response rate levels and trends in organizational research", Human Relations, Vol. 61 No. 8, pp. 1139-1160.

Baruch, Y., Grimland, S. and Vigoda-Gadot, E. (2014), "Professional vitality and career success: mediation, age and outcomes", European Management Journal, Vol. 32 No. 3, pp. 518-527.

Bloom, D.E., Boersch-Supan, A., McGee, P. and Seike, A. (2011), "Population aging: facts, challenges, and responses", Benefits and Compensation International, Vol. 41 No. 1, pp. 22-28.

Botterweck, A.A.M. (2003). Psychische werkbelasting en gezondheidsklachten. Sociaaleconomische maandstatistiek, Vol. 20 No. 10, pp. 23-27

Bradshaw, J. and Mayhew, E. (2003), “Are welfare states financing their growing elderly populations at the expense of their children?”, Family Matters, Vol. 66, Spring/Summer, No. 66, pp. 20-25.

Busse, R., Wurzburg, G. and Zappacosta, M. (2003), "Shaping the Societal Bill: past and future trends in education, pensions and healthcare expenditure", Futures, Vol. 35 No. 1, pp. 7-24.

Cau-Bareille, D., Gaudart, C. and Delgoulet, C. (2012), "Training, age and technological change: difficulties associated with age, the design of tools, and the organization of work", Work, Vol. 41 No. 2, pp. 127-141.

Christensen, H. (2001), "What cognitive changes can be expected with normal ageing?", Australian and New Zealand Journal of Psychiatry, Vol. 35 No. 6, pp. 768-775.

Conen, W.S., Van Dalen, H.P. and Henkens, K. (2012), “Ageing and employers' perceptions of labour costs and productivity: a survey among European employers", International Journal of Manpower, Vol. 33 No. 6, pp. 629-647.

De Lange, A.H., Taris, T.W., Jansen, P..G.W., Smulders, P., Houtman, I.L.D. and Kompier, M.A.J. (2006), "Age as a factor in the relation between work and mental health: results from the longitudinal TAS study", in Houdmont, J. and McIntyre, S. (Eds), Occupational Health Psychology: European Perspectives on Research, Education and Practice, Maia: ISMAI Publications, pp. 21-45. Occupational Health Psychology: European Perspectives on Research, Education and Practice, Vol. 1, pp. 21-45. 
De Vries, S.D., van Gründemann, R. and van Vuuren, T.V. (2001), "Employability policy in Dutch organizations", International Journal of Human Resource Management, Vol. 12 No. 7, pp. $1193-1202$.

Euwals, R., De Mooij, R. and Van Vuuren, D. (2009), Rethinking Retirement. From Participation Towards Allocation, Centraal Planbureau, Den Haag.

Froehlich, D.M., Beausaert, S., Segers, M. and Gerken, M. (2014), "Learning to stay employable”, Career Development International, Vol. 19 No. 5, pp. 508-525.

Giles, H., Noels, K., Ota, H., Hung Ng, S., Gallois, C., Ryan, E.B., Williams, A., Lim, T., Somera, L., Tao, H. and Sachdev, I. (2000), “Age vitality across eleven nations", Journal of Multilingual and Multicultural Development, Vol. 2 No. 4, pp. 308-323.

Ilies, R., Dimotakis, N. and De Pater, I.E. (2010), "Psychological and physiological reactions to high workloads: implications for well-being", Personnel Psychology, Vol. 63 No. 2, pp. 407-436.

Ilmarinen, J. (2001), “Aging workers”, Occupational Environmental Medicine, Vol. 58 No. 8, pp. 546-552.

Ilmarinen, J. (2007), “The work ability index (WAI)", Occupational Medicine, Vol. 57 No. 2, pp. 160-160.

Jackson, M.A. (2013), "Counseling older workers confronting ageist stereotypes and discrimination”, in Brownell, P. and Kelly, J. (Eds), Ageism and Mistreatment of Older Workers, Springer, Dordrecht, pp. 135-144.

Jettinghoff, K. and Houtman, I.L.D. (2002), Literatuuronderzoek en secundaire analyses naar de werkbelasting van oudere en jongere politiemedewerkers, TNO, Hoofddorp.

Koppers, L.L.J., de Vroome, E.M.M., Mars, G.M.J., Janssen, B.J.M., van Zwieten, M.H.J. and Van den Bossche, S.N.J. (2012), "Nationale Enquête Arbeidsomstandigheden. Methodologie en globale resultaten", TNO: Leiden, The Netherlands.

Levy, S.R. and Macdonald, J.L. (2016), "Progress on understanding ageism”, Journal of Social Issues, Vol. 72 No. 1, pp. 5-15.

Loretto, W. and White, P. (2006), "Employers' attitudes, practices and policies towards older workers", Human Resource Management Journal, Vol. 16 No. 3, pp. 313-330.

Miles, D. (1999), "Modelling the impact of demographic change upon the economy", The Economic Journal, Vol. 109 No. 452, pp. 1-36.

Nauta, A., De Bruin, M.R. and Cremer, R. (2004), De mythe doorbroken. Gezondheid en inzetbaarheid oudere werknemers, TNO Arbeid, Hoofddorp.

Nauta, A., De Vroome, E., Cox, E., Korver, T. and Kraan, K. (2005), "De invloed van functietype op het verband tussen leeftijd en inzetbaarheid”, Gedrag \& Organisatie, Vol. 18 No. 6, pp. 326-337.

Nauta, A., Van der Heijden, B., Van Vianen, A., Preenen, P. and Van Dam, K. (2007), “The impact of job type on relationships between age and the motivation and obligation to change jobs", 13th European Congress of Work and Organizational Psychology, EAWOP 2007: Sustainable Work: Promoting Human and Organizational Vitality.

Noonan, A.E. (2005), "At this point now: older workers' reflections on their current employment experiences”, International Journal of Aging \& Human Development, Vol. 61 No. 3, pp. 211-241.

OECD (2006), Live Longer, Work Longer, OECD, Paris.

Rothwell, A. and Arnold, J. (2007), "Self-perceived employability: development and validation of a scale”, Personnel Review, Vol. 36 No. 1, pp. 23-41.

Ryan, R.M. and Frederick, C. (1997), "On energy, personality, and health: subjective vitality as a dynamic reflection of well-being", Journal of Personality, Vol. 65 No. 3, pp. 529-565.

Semeijn, J.H., Van Dam, K., Van Vuuren, T. and Van der Heijden, B.I.J.M. (2015), "Sustainable labour participation and sustainable careers", Handbook of Research on Sustainable Careers, Edward Elgar Publishing, Chaltenham, MA, pp. 146-160.

Shultz, K.S., Morton, K.R. and Weckerle, J.R. (1998), "The influence of push and pull factors on voluntary and involuntary early retirees' retirement decision and adjustment", Journal of Vocational Behavior, Vol. 53 No. 1, pp. 45-57. 
Strijk, J.E., Wendel-Vos, G.C.W., Picavet, H.S.J., Hofstetter, H. and Hildebrandt, V.H. (2015), "Wat is vitaliteit en hoe is het te meten? Kerndimensies van vitaliteit en de Nederlandse Vitaliteitsmeter", TSG, Vol. 93 No. 1, pp. 32-40.

Tengland, P.A. (2011), "The concept of work ability", Journal of Occupational Rehabilitation, Vol. 21 No. 2, pp. 275-285.

Tims, M. and Bakker, A.B. (2010), "Job crafting: towards a new model of individual job redesign", Journal of Industrial Psychology, Vol. 36 No. 2, pp. 1-9.K.

Tisch, A. (2015), "Firms' contribution to the internal and external employability of older employees: evidence from Germany”, European Journal of Ageing, Vol. 12 No. 1, pp. 29-38.

Van Dalen, H.P., Henkens, K. and Schippers, J. (2010), "Productivity of older workers: perceptions of employers and employees", Population and Development Review, Vol. 36 No. 2, pp. 309-330.

Van der Heijden, B. (2002), "Prerequisites to guarantee life-long employability", Personnel Review, Vol. 31 No. 1, pp. 44-61.

Van der Klink, J.J.L., Bültmann, U., Brouwer, S., Burdorf, A., Schaufeli, W.B., Zijlstra, F.R.H. and Van der Wilt, G.J. (2011), "Duurzame inzetbaarheid bij oudere werknemers, werk als waarde", Gedrag \& Organisatie, Vol. 24 No. 4, pp. 342-356.

Van Jaarsveld, D.D., Walker, D.D. and Skarlicki, D.P. (2010), "The role of job demands and emotional exhaustion in the relationship between customer and employee incivility", Journal of Management, Vol. 36 No. 6, pp. 1486-1504.

Van Veldhoven, M. and Meijman, T. (1994), Het meten van psychosociale arbeidsbelasting met een vragenlijst. De vragenlijst beleving en beoordeling van arbeid (VBBA), Nederlands instituut voor arbeidsomstandigheden NIA: Amsterdam, The Netherlands.

Van Vuuren, T. and Marcelissen, F. (2013), "Work ability, vitality and employability according to age and education in primary education", Tijdschrift HRM, Vol. 16 No. 2, pp. 45-62.

Van Vuuren, T., Caniëls, M.C.J. and Semeijn, J.H. (2011), "Duurzame inzetbaarheid en een leven lang leren", Gedrag en organisatie, Vol. 24 No. 4, pp. 357-374.

Visser, P.S., Krosnick, J.A., Marquette, J. and Curtin, M. (1996), "Mail surveys for election forecasting? An evaluation of the Columbus dispatch poll", Public Opinion Quarterly, Vol. 60 No. 2, pp. 181-227.

Zoer, I., Ruitenburg, M.M., Botje, D., Frings-Dresen, M.H.W. and Sluiter, J.K. (2011), "The associations between psychosocial workload and mental health complaints in different age groups", Ergonomics, Vol. 54 No. 10, pp. 943-952.

\section{Corresponding author}

Brenda Vermeeren can be contacted at: vermeeren@essb.eur.nl

For instructions on how to order reprints of this article, please visit our website:

www.emeraldgrouppublishing.com/licensing/reprints.htm

Or contact us for further details: permissions@emeraldinsight.com 